\title{
IN VITRO PROPAGATION OF SEARSIA TRIPARTITA (UCRIA) MOFFETT AS AN ENDANGERED MEDICINAL PLANT
}

\author{
Heba Elsayed Ghareb* and Mahdia Farid Gabr \\ Tissue Culture Unit, Department of Genetic Resources, Desert Research \\ Center, El-Matareya, Cairo, Egypt \\ *E-mail: hebaghareb_drc@yahoo.com
}

\begin{abstract}
A
$\mathrm{n}$ effective protocol for micropropagation of the endangered Searsia tripartita plant (Anacardiaceae) was developed. Shoot tips and stem node sections from the mature plant and diverse explants from seedlings were used as explants. Murashige and Skoog (MS) medium supplemented with $0.1 \mathrm{mg} \mathrm{L}^{-1}$ naphthalene acetic acid (NAA) and $1.5 \mathrm{mg} \mathrm{L}^{-1}$ benzyl adenine (BA) induced the highest mean length of shoots $5.8,6.6$ and $5.3 \mathrm{~cm}$ for shoot tips from mature plants, shoot tips and stem node sections from seedlings, respectively. This medium also provided the highest percentage of growth induction with these three explants. The medium supplemented with $0.1 \mathrm{mg}$ $\mathrm{L}^{-1} \mathrm{NAA}$ and $\mathrm{BA}$ at $1.0 \mathrm{mg} \mathrm{L}^{-1}$ induced the maximum mean length of shoots $(3.4 \mathrm{~cm})$ with the stem sections from mature plants. A length of the shoot of $4.7 \mathrm{~cm}$ was gained from the hypocotyl explant with MS medium free from plant growth regulators (PGRs). MS medium supplemented with several concentrations of either BA or kinetin (Kin) were used to determine their influence on shoot multiplication. The highest rooting percentage recorded $70 \%$ on MS medium supplemented with $3.0 \mathrm{mg} \mathrm{L}^{-1} \mathrm{IBA}$ with $100 \mathrm{mg} \mathrm{L}^{-1}$ phloroglucinol (PG) and $1 \mathrm{~g}$ $\mathrm{L}^{-1}$ activated charcoal (AC). An average of $50-60 \%$ of the in vitro derived transplants were survived after transferring into greenhouse conditions. Five phenolic compounds with numerous health benefits were detected by HPLC in a comparative study between mother plant, in vitro multiplied plants and acclimatized plants to determine which of them contains high amount of phenolic compounds.
\end{abstract}

Keywords: Sumac, rare, micropropagation, phenolic compounds, HPLC 
Searsia tripartita (Ucria) Moffett (Synonyms Rhus tripartita (Ucria) Grande) is a member of Anacardiaceae family, which consists of approximately 73 genera and 600 species. Searsia (Rhus) is the most important genus in this family. Sumac is the common name for this genus, which includes more than 250 species (Täckholm, 1974). This genus extract showed antimalarial, antimicrobial, antitumori genic, antioxidant, antiviral, hypoglycaemic, leukopenic, atherosclerosis and anticonvulsant properties (Itidel et al., 2013). Also, this genus has been used for the treatment of diarrhea, colitis, GIT diseases, inflammatory diseases, diabetes, dysentery, haemoptysis, conjunctivitis, animal bites poisons, hemorrhoids, sexual disease, fever, pain and various cancers. Different parts of this plant have been used to isolate flavonoids, biflavonoids, isobiflavonoids, catechin, epicatechin-3-O-gallate, proanthocyanidin oligomers, polymers, polysaccharides and condensed tannins (Mohammed, 2015). S. tripartita is a deciduous shrub, reaching 1-2 $\mathrm{m}$ high and grown in limestone slopes and hard rock crevices. This plant is distributed in North Africa (Itidel et al., 2013). In Egypt, it is an endangered plant (El-hadidi et al., 1991) present in Gable Elba, South Egypt. It is widely added to food, used in modern and traditional medicine. The fruits of this plant are edible, and the infusion of the fruits and the leaves is recommended for gastric and intestinal ailments. The fruits are consumed fresh, added to drinking water or soaked in milk to offer an acceptable taste. Leaves contain 18 kinds of flavonoids (Furth and Young, 1988). The plant extract contains also high phenolic content, vitamin $\mathrm{E}$ and flavonoid substances, so it is used as anti-inflammatory and antioxidant products (Mahjoub et al., 2010). Phenolics have several health benefits; ellagic acid is a natural phenolic compound. It is a powerful antioxidant since it removes several toxins from the body and has a free radical scavenging activity. Zhang et al. (2014) found that ellagic acid prevents many types of cancer by breaking the binding of DNA with different carcinogens and causing cell apoptosis. Ferulic acid, is a ubiquitous natural phenolic phytochemical. This compound has many industrial and biological usages. It is known as an antioxidant, antidiabetic, antiaging agent. Also, it is used in food discoloration, growth enhancing agent, a precursor of vanillin, as an anticancer agent and also used in cosmetics (Kumar and Pruthi, 2014). Coumarins are an important class of heterocyclic compounds belonging to the benzopyrone family. They are effective in treatment of variety of cancer and exhibit many properties such as; antitumor, anti-viral, anti-inflammatory, anti-coagulant, anti-oxidant, antimicrobial and enzyme inhibitor (Padte et al., 2017). Quercetin is an important flavonoid used for the treatment of cancer (Kumar et al. (2017). Kaempferol is another flavonoid and has major role in the risk of reduction of developing many disorders as cancer and cardiovascular diseases (Montano et al., 2011). Variation in secondary metabolite amounts between in vitro regenerated plants and their wild counterparts as a response to 
environmental alteration has been reported in many plant species (Chintalwar et al., 2003 and Ranjitha Kumari et al., 2007).

Also, the plant extract has cardiovascular beneficial effects (Shahat et al., 2016). It has been used as a natural dye (Gargoubi et al., 2015). Plant extract inhibits Agrobabacterium tumefacien in vitro and suppressed tumor formation on tomato roots in greenhouse (Al-Kurdi et al., 2000). Use of this species as a fodder plant led to difficulties in its vegetative propagation because of overgrazing, which make this plant endangered and needs conservation. There is a demand for developing new methods for efficient and quick propagation. Plant tissue culture as a technology for ex situ multiplication is fast, uses small amounts of shoots or seeds and may succeed when other methods fail (Ye et al., 2011). In recent years, there has been an increased interest in in vitro culture techniques that offer available tool for mass multiplication and germplasm conservation of rare, endangered, aromatic and medicinal plants (Jamal et al., 2011). Although the wide application of plant tissue culture methodology; little is published on Sumac micropropagation. Concerning S. tripartita micropropagation, at the best of our knowledge, this is the first publication on the in vitro propagation of this plant. The aim of this work was to establish a suitable method for the propagation of $S$. tripartita plant via micropropagation technique. Also, comparing the phenolic content between the mother plant, the in vitro multiplied plant and the acclimatized plant. Finally, obtaining a preknowledge about the effect of micropropagation techniques on the phenolic compounds content in the produced plants by comparing them with the mother plant.

\section{MATERIALS AND METHODS}

\section{Plant Material}

Two different sources were used for preparation of the plant material used in this study. Mother plant as a mature source and in vitro growing seedlings. From the mature source two types of explants were used; shoot tips and stem node sections. However, from the in vitro growing seedlings; three different types of explants were tried; shoot tips, stem node sections and the hypocotyls. Explants prepared from shrubs were collected during spring and summer. For those prepared from in vitro growing seedlings were collected all over the year.

\section{Explant Preparation and Sterilization}

Plant materials were washed under running tap water for 20-30 min. For sterilization, explants were soaked in different concentrations $(0.5,0.8$ and $0.8,1.5 \%$ for shoot tips and stem node sections, respectively) of sodium hypochlorite solution for different periods of 5 and $10 \mathrm{~min}$ for shoot tips and 15 and 20 min for stem node sections. 
Seeds were surface sterilized by soaking in $70 \%$ ethanol for 10 min, then rinsing 4-5 times with sterile distilled water and then the explants were transferred to $2.5 \%$ sodium hypochlorite solution for $15 \mathrm{~min}$, finally washed four times with sterile distilled water.

\section{Culture Medium and Conditions}

The culture medium in the present work was Murashige and Skoog (MS) salts and vitamins (Murashige and Skoog, 1962) supplemented with $100 \mathrm{mg} \mathrm{L}^{-1}$ myo-inositol, 3\% (w/v) sucrose and $1 \mathrm{~g} \mathrm{~L}^{-1}$ activated charcoal (AC). The medium was further supplemented with different combinations of plant growth regulators (PGRs) according to the requirements of every growth stage, in addition to the control medium without PGRs. The $\mathrm{pH}$ of the medium was adjusted to 5.7-5.8 before the addition of $0.3 \%(\mathrm{w} / \mathrm{v})$ phytagel.

The sterilized explants from the mature plant (shoot tips, stem node sections) and seeds were cultured on the media under complete aseptic conditions in the Laminar Air Flow Hood. Cultured explants were placed in an incubation room at $26 \pm 2^{\circ} \mathrm{C}$ under a photoperiod of 16 hours. Two months old seedlings were used as a source for shoot tips, stem node sections and hypocotyls for shoot culture experiments.

\section{Shoot Initiation and Multiplication}

For shoot initiation, explants were cultured on MS medium supplemented with 6-benzyl adenine (BA) at concentrations of $0.25,0.5,1.0$ and $1.5 \mathrm{mg} \mathrm{L}^{-1}$, in combination with $0.1 \mathrm{mg} \mathrm{L}^{-1} \beta$-naphthalene acetic acid (NAA) in addition to MS medium free PGRs as control. After 12 weeks of culture, the percentage of survived explants (\%), growth induction percentage $(\%)$ and mean length of shoots $(\mathrm{cm})$ were recorded for shoot tips and stem node sections from the mature plant. Growth induction percentage $(\%)$ and mean length of shoots $(\mathrm{cm})$ were recorded for shoot tips, stem node sections and hypocotyls from the seedlings after 8 weeks of culture.

For shoot multiplication, MS medium was supplemented with kinetin (Kin) or BA, individually at concentrations of 2, 3 and $4 \mathrm{mg} \mathrm{L}^{-1}$ for each, in addition to the control treatment of MS medium free PGRs. Mean number of shoots per explant and the mean length of shoots $(\mathrm{cm})$ were recorded after 8 weeks.

\section{Rooting of Shoots}

The multiplied shoots as clusters placed in rooting medium in $1 / 4$ strength MS salts and vitamins in addition to $100 \mathrm{mg} \mathrm{L}^{-1}$ myo inositol, 100 $\mathrm{mg} \mathrm{L}^{-1}$ phloroglucinol (PG) and different concentrations (1, 2, 3, 4 and $5 \mathrm{mg}$ $\mathrm{L}^{-1}$ ) of indole butyric acid (IBA) with $1 \mathrm{~g} \mathrm{~L}^{-1} \mathrm{AC}$. After 8 weeks, rooting percentage, mean number of roots per cluster and mean length of roots $(\mathrm{cm})$ were recorded. 


\section{Acclimatization}

The rooted plantlets were removed gently from the medium and washed with sterile distilled water. Plantlets were then transferred to plastic pots filled with a sterilized mixture of sand, peat moss and vermiculite at equal volumes. They were covered with plastic bags and transferred to greenhouse $\left(28 \pm 2^{\circ} \mathrm{C}, 70-80 \%\right.$ relative humidity). After three weeks, plastic bags were gradually removed from pots for proper hardening, and plantlets were irrigated with tap water every three days. Three months old plantlets were transferred in larger pots outside the greenhouse. After another six months, the plantlets were transferred to the soil.

\section{Extraction and Determination of Phenolic Compounds}

The aerial parts of the mother plant, in vitro multiplied plant and the acclimatized plants of $S$. tripartita were collected and dried. The dried samples were powdered in a mortar using a pestle before being used for solvent extraction. For the preparation of extract, $3 \mathrm{~g}$ of fine powder was extracted with $14 \mathrm{ml}$ of $70 \%$ ethanol at room temperature for 24 hours. The extracts were filtrated through filter paper. The ethanol was evaporated from the supernatants under vacuum with a rotary evaporator at $70^{\circ} \mathrm{C}$. After evaporation, the extract was concentrated and resuspended in $70 \%$ ethanol. Phenolic compounds were extracted from the three filtrated samples. Samples were analyzed by high performance liquid chromatography (HPLC) (Dionex Ultimate 3000, Germany) in the Central Laboratory, Desert Research Center using a method based on that described by Rispail et al. (2005). The HPLC system equipped with an auto-sampler, quaternary pump and a diode array detector. The analytical column was BDS Hypersil C18 column $(250 \times 4.6 \mathrm{~mm})$ thermostated at $40^{\circ} \mathrm{C}$. Separation was performed with acetonitrile and deionized water $(60: 40 \mathrm{v} / \mathrm{v})$ as the elusion solvent at flow rate of $1 \mathrm{ml} \mathrm{min}^{-1}$ and the detection wavelength was $246 \mathrm{~nm}$.

\section{Experimental Design and Statistical Analysis of Data}

The experiments were repeated twice and treatments for each experiment were represented by at least 10 replicates. Data of all experiments were statistically analyzed and subjected to the completely randomized design. Anova program for statistical analysis was used for variance analysis of data. The differences among means for all treatments were tested for significance at 5\% level using Duncan's multiple range test (Duncan, 1955).

\section{RESULTS AND DISCUSSION}

\section{Sterilization of Shoot Tip and Stem Node Section Explants}

In the present investigation two types of explants were subjected to different concentrations of sodium hypochlorite for sterilization (Table 1). In 
the case of shoot tips, the highest survival percentage was $90.7 \%$, which was achieved by $0.5 \%$ sodium hypochlorite for $10 \mathrm{~min}$. While in the case of stem node sections, the highest survival percentage was $93.0 \%$ using $1.5 \%$ of sodium hypochlorite for $15 \mathrm{~min}$. Despite all treatments used for sterilization, contamination still persists as a difficult problem. This is possibly due to some endogenous microorganisms that are harbored within the explant tissue. Some of these contaminations are slow growing or latent and will not visually apparent for several subcultures (Hu and Wang, 1983).

Table (1). Effect of surface sterilization with different concentrations of sodium hypochlorite $(\mathrm{NaOCl})$ solution and durations on the survival percentage of shoot tip and stem node section explants of Searsia tripartita.

\begin{tabular}{cccccc}
\hline & Shoot tip & \multicolumn{3}{c}{ Stem node section } \\
\hline $\begin{array}{c}\text { NaOCl } \\
\text { conc. (\%) }\end{array}$ & $\begin{array}{c}\text { Duration } \\
\text { (min) }\end{array}$ & $\begin{array}{c}\text { Survival } \\
(\%)\end{array}$ & $\begin{array}{c}\text { NaOCl } \\
\text { conc. }(\%)\end{array}$ & $\begin{array}{c}\text { Duration } \\
\text { (min) }\end{array}$ & $\begin{array}{c}\text { Survival } \\
(\%)\end{array}$ \\
\hline 0.5 & 5 & 73.0 & 0.8 & 15 & 60.14 \\
0.5 & 10 & 90.7 & 0.8 & 20 & 74.28 \\
0.8 & 5 & 71.2 & 1.5 & 15 & 93.00 \\
0.8 & 10 & 62.0 & 1.5 & 20 & 69.00 \\
\hline
\end{tabular}

\section{Seeds Sterilization and Germination}

The percentage of seed survival after sterilization was 99\%. They were germinated on MS medium without PGRs. After 8 weeks of culture, the germination percentage reached about $50 \%$.

\section{Shoot Initiation}

The primary goal of this stage is to obtain a large percentage of explants free from surface pathogens (Murashige, 1974). Choice of explant, elimination of contamination, and culture conditions are the main factors that affect the success of this stage (Hartmann and Kester, 1983).

Data in table (2) and (3) show that axillary shoots can form on all tested media from all types of explants. For shoot tips and stem node sections from mature plants, the percentage of shoot tip survival ranged from 60.2 to $95 \%$ (Table 2) (Fig. 1a). However, the growth induction percentage reached $88 \%$ in medium supplemented with $0.1 \mathrm{mg} \mathrm{L}^{-1} \mathrm{NAA}+1.5 \mathrm{mg} \mathrm{L}^{-1}$ BA. The survival percentage was $100 \%$ in the same medium for stem node sections, which also gave the highest percentage of growth induction (96.5\%). However, MS medium supplemented with $0.1 \mathrm{mg} \mathrm{L}^{-1} \mathrm{NAA}+1.0$ $\mathrm{mg} \mathrm{L}^{-1} \mathrm{BA}$ gave the highest mean length of shoots $(3.4 \mathrm{~cm})$. From table (2), it is noticed that the two media supplemented with high concentrations of BA (1.5 and $\left.1.0 \mathrm{mg} \mathrm{L}^{-1}\right)$ with $0.1 \mathrm{mg} \mathrm{L}^{-1} \mathrm{NAA}$ gave the highest mean length of shoots of 5.8 and $3.4 \mathrm{~cm}$ for both shoot tips and stem node sections, 
respectively. Oliveira et al. (2015) have also recorded similar results on micropropagation of Eucalyptus cloeziana using WPM supplemented with more than $0.6 \mathrm{mg} \mathrm{L}^{-1} \mathrm{BA}+0.1 \mathrm{mg} \mathrm{L}^{-1} \mathrm{NAA}$.

Table (2). Effect of PGRs (NAA and BA) and explant type of mature Searsia tripartita on in vitro shoot initiation on MS medium after 12 weeks of culture.

\begin{tabular}{cccccccc} 
Conc. $\left(\mathbf{m g ~ L ~}^{-1}\right)$ & \multicolumn{3}{c}{ Shoot tip } & \multicolumn{3}{c}{ Stem node sections } \\
\hline NAA & $\mathbf{B A}$ & $\begin{array}{c}\text { Survived } \\
\text { explants } \\
(\%)\end{array}$ & $\begin{array}{c}\text { Growth } \\
\text { induction } \\
(\%)\end{array}$ & $\begin{array}{c}\text { Mean } \\
\text { length of } \\
\text { shoots } \\
\text { (cm) }\end{array}$ & $\begin{array}{c}\text { Survived } \\
\text { explants } \\
(\%)\end{array}$ & $\begin{array}{c}\text { Growth } \\
\text { induction } \\
(\%)\end{array}$ & $\begin{array}{c}\text { Mean } \\
\text { length of } \\
\text { shoots } \\
(\mathbf{c m})\end{array}$ \\
\hline $\mathbf{0 . 0}$ & $\mathbf{0 . 0 0}$ & 95.0 & 50.0 & $3.7^{\mathrm{c}}$ & 85.5 & 49.1 & $2.3^{\mathrm{bc}}$ \\
$\mathbf{0 . 1}$ & $\mathbf{0 . 2 5}$ & 90.1 & 50.0 & $4.0^{\mathrm{c}}$ & 85.7 & 50.0 & $2.0^{\mathrm{bc}}$ \\
$\mathbf{0 . 1}$ & $\mathbf{0 . 5 0}$ & 85.0 & 62.5 & $4.3^{\mathrm{bc}}$ & 94.1 & 70.2 & $2.0^{\mathrm{bc}}$ \\
$\mathbf{0 . 1}$ & $\mathbf{1 . 0 0}$ & 60.2 & 80.0 & $5.1^{\mathrm{ab}}$ & 87.4 & 71.4 & $3.4^{\mathrm{a}}$ \\
$\mathbf{0 . 1}$ & $\mathbf{1 . 5 0}$ & 94.0 & 88.0 & $5.8^{\mathrm{a}}$ & 100.0 & 96.5 & $2.6^{\mathrm{ab}}$ \\
\hline
\end{tabular}

In each column, means followed by the same letter are not significantly different $(p<0.05)$ according to Duncan's multiple range test.

Table (3). Effect of PGRs (NAA and BA) and explant type of Searsia tripartita seedlings on in vitro shoot initiation on MS medium after 8 weeks of culture.

\begin{tabular}{cccccccc}
\hline \multicolumn{2}{c}{$\begin{array}{c}\text { Conc. } \\
\left(\mathbf{m g ~ L} \mathbf{L}^{-1}\right)\end{array}$} & \multicolumn{2}{c}{ Shoot tip } & \multicolumn{2}{c}{ Stem node section } & \multicolumn{2}{c}{ Hypocotyl } \\
\hline NAA & $\mathbf{B A}$ & $\begin{array}{c}\text { Growth } \\
\text { induction } \\
(\%)\end{array}$ & $\begin{array}{c}\text { Mean } \\
\text { length } \\
\text { of shoots } \\
(\mathbf{c m})\end{array}$ & $\begin{array}{c}\text { Growth } \\
\text { induction } \\
(\%)\end{array}$ & $\begin{array}{c}\text { Mean } \\
\text { length } \\
\text { of shoots } \\
(\mathbf{c m})\end{array}$ & $\begin{array}{c}\text { Growth } \\
\text { induction } \\
(\%)\end{array}$ & $\begin{array}{c}\text { Mean } \\
\text { length } \\
\text { of shoots } \\
(\mathbf{c m})\end{array}$ \\
\hline $\mathbf{0 . 0}$ & $\mathbf{0 . 0 0}$ & 91.0 & $1.8^{\text {cd }}$ & 92.3 & $4.4^{\text {ab }}$ & 97.2 & $4.7^{\text {a }}$ \\
$\mathbf{0 . 1}$ & $\mathbf{0 . 2 5}$ & 91.4 & $2.9^{\mathrm{c}}$ & 95.7 & $4.5^{\mathrm{ab}}$ & 96.7 & $3.3^{\mathrm{ab}}$ \\
$\mathbf{0 . 1}$ & $\mathbf{0 . 5 0}$ & 92.9 & $4.4^{\mathrm{b}}$ & 96.6 & $4.6^{\mathrm{ab}}$ & 95.0 & $4.0^{\mathrm{ab}}$ \\
$\mathbf{0 . 1}$ & $\mathbf{1 . 0 0}$ & 96.6 & $5.6^{\mathrm{ab}}$ & 97.1 & $4.8^{\mathrm{ab}}$ & 94.8 & $3.4^{\mathrm{ab}}$ \\
$\mathbf{0 . 1}$ & $\mathbf{1 . 5 0}$ & 97.6 & $6.6^{\mathrm{a}}$ & 98.0 & $5.3^{\mathrm{a}}$ & 93.3 & $3.0^{\mathrm{bc}}$ \\
\hline
\end{tabular}

In each column, means followed by the same letter are not significantly different $(p<0.05)$ according to Duncan's multiple range test.

Browning in this stage led to several problems especially with explants from mature source. In all tested media in this experiment, AC was added in $1 \mathrm{~g} \mathrm{~L}^{-1}$ to avoid browning injuries. Senarath (2010) reported that 
browning is a major problem in plant tissue culture, so the juvenile sources in micropropagation is usually preferred in several plant species. Das and Srivastav (2015) found that explant death in Aloe vera can be caused by oxidation of phenolic compounds, which can be reduced by addition of AC at $2 \mathrm{~g} \mathrm{~L}^{-1}$. During the propagation of Pomegranate (Punica granatum), addition of $\mathrm{AC}$ at $200 \mathrm{mg} \mathrm{L}^{-1}$ into the medium reduces browning in nodal segments of mature explants (Singh and Patel, 2016).

Explants form shoots when the concentration of cytokinins is higher than auxin. In the initiation stage, low concentrations of auxin in combination with high concentrations of cytokinins increases apical dominance and promotes growth without inducing callus formation (George et al., 2008). The combination between auxins and cytokinins promotes shoot growth and in vitro multiplication of many plant species (Fracaro and Echeverrigaray, 2001).

For the shoot tips and stem node sections from seedlings, data shown in table (3) indicate that for shoot tip explants, the growth induction percentage ranged from 91.0 to $97.6 \%$. MS medium supplemented with 0.1 $\mathrm{mg} \mathrm{L} \mathrm{L}^{-1} \mathrm{NAA}$ and $1.5 \mathrm{mg} \mathrm{L}^{-1} \mathrm{BA}$ gave the highest growth induction percentage $(97.6 \%)$ and the highest mean length of shoot $(6.6 \mathrm{~cm})$ (Fig. 1b).

Concerning the stem node sections, differences were approximately insignificant in all tested media for the mean length of shoots. However, the medium supplemented with $0.1 \mathrm{mg} \mathrm{L}^{-1} \mathrm{NAA}+1.5 \mathrm{mg} \mathrm{L}^{-1} \mathrm{BA}$ gave the highest mean length of shoots $(5.3 \mathrm{~cm})$ and also gave the highest growth induction percentage $(98 \%)$. Moreover, it can be noticed that the growth induction percentage and the mean length of shoots increased by increasing BA concentration, this can be explained by the presence of $0.1 \mathrm{mg} \mathrm{L}^{-1} \mathrm{NAA}$ in the media in addition to the endogenous auxin in the plant. Results of the establishment of stem node sections agree with Cheruvathur et al. (2015), who claimed that MS medium supplemented with $3.0 \mathrm{mg} \mathrm{L}^{-1} \mathrm{BA}$ and $0.5 \mathrm{mg}$ $\mathrm{L}^{-1}$ NAA induced the highest shoot induction response in Ipomoea sepiaria, an important ethanomedicinal plant. Keng et al. (2009) reported that shoot proliferation from nodal segments of Gynura procumbens, an important medicinal plant, was achieved by culturing on MS medium with $2.0 \mathrm{mg} \mathrm{L}^{-1}$ $\mathrm{BA}$ and $0.5 \mathrm{mg} \mathrm{L}^{-1} \mathrm{NAA}$.

For hypocotyl explants, it was noticed that MS medium without PGRs was the best medium for the mean length of shoots $(4.7 \mathrm{~cm})$ and the percentage of growth decreased by increasing BA concentration (Table 3 ).

In conclusion, the best medium for establishment of all tested explants was MS medium supplemented with $0.1 \mathrm{mg} \mathrm{L}^{-1} \mathrm{NAA}+1.5 \mathrm{mg} \mathrm{L}^{-1}$ BA since it gave the highest growth percentage, mean length of shoots and there were no significant differences between this medium and that containing $0.1 \mathrm{mg} \mathrm{L}^{-1} \mathrm{NAA}+1.0 \mathrm{mg} \mathrm{L}^{-1} \mathrm{BA}$ for mature stem node sections. Only the hypocotyl explants preferred MS free PGRs. The best explant for shoot initiation was the shoot tip from juvenile source since it gave the 
highest mean length of shoot. The juvenile explant source was more advisable than the mature source because of the death occurs to mature shoots after subculturing because of browning. There is an inverse correlation between the explant age and the regeneration capacity, since the regeneration capacity decreases with older explant source (Yildiz et al., 2002).

\section{Shoot Multiplication}

The results of multiplication of the in vitro established $S$. tripartita shoots are presented in table (4). Stem node sections were placed in MS medium supplemented with different concentrations of Kin or BA (2, 3.0 and $4.0 \mathrm{mg} \mathrm{L}^{-1}$ ) in addition to MS basal medium free of PGRs.

Table (4). Effect of cytokinin (BA or Kin) on shoot multiplication of Searsia tripartita after 8 weeks.

\begin{tabular}{|c|c|c|c|}
\hline \multicolumn{2}{|c|}{ Conc. $\left(\mathrm{mg} \mathrm{L}^{-1}\right)$} & \multirow{2}{*}{$\begin{array}{c}\text { Mean number of } \\
\text { shoots/explant }\end{array}$} & \multirow{2}{*}{$\begin{array}{l}\text { Mean length of } \\
\text { shoot }(\mathrm{cm})\end{array}$} \\
\hline BA & Kin & & \\
\hline 0.0 & 0.0 & $1.25^{\mathrm{c}}$ & $4.9^{\mathrm{a}}$ \\
\hline 0.0 & 2.0 & $1.75^{\mathrm{c}}$ & $3.8^{\mathrm{b}}$ \\
\hline 0.0 & 3.0 & $2.25^{\mathrm{bc}}$ & $5.4^{\mathrm{a}}$ \\
\hline 0.0 & 4.0 & $3.00^{\mathrm{b}}$ & $2.5^{\mathrm{c}}$ \\
\hline 2.0 & 0.0 & $3.10^{\mathrm{b}}$ & $3.6^{\mathrm{b}}$ \\
\hline 3.0 & 0.0 & $4.00^{\mathrm{a}}$ & $4.8^{\mathrm{a}}$ \\
\hline 4.0 & 0.0 & $2.50^{\mathrm{bc}}$ & $4.2^{\mathrm{b}}$ \\
\hline
\end{tabular}

In each column, means followed by the same letter are not significantly different $(p<0.05)$ according to Duncan's multiple range test.

It was noticed that $\mathrm{BA}$ was more effective than Kin regarding to the mean number of shoots. Shoots cultured on MS medium supplemented with $3 \mathrm{mg} \mathrm{L}^{-1} \mathrm{BA}$ gave the highest mean number of shoots / explant (4 shoots) with mean length of shoots of $4.8 \mathrm{~cm}$ (Fig. 1c). Medium fortified with $2 \mathrm{mg}$ $\mathrm{L}^{-1} \mathrm{BA}$ gave the second highest shoot number (3.1 shoots) of $3.6 \mathrm{~cm}$ in length. However, increasing BA concentration than $3.0 \mathrm{mg} \mathrm{L}^{-1}$ gave lower mean number of shoots. Concerning Kin, there was a positive correlation between shoot multiplication rates and the concentrations of Kin. The highest mean number of shoots (3 shoots) was obtained with the highest concentration of Kin $\left(4 \mathrm{mg} \mathrm{L}^{-1}\right)$ Kin. Dan and Reichert (2001) reported that shoot regeneration process needs cytokinins as a primary hormone at optimum concentrations. In vitro regeneration with high number of shoots per explant using BA were demonstrated in many woody and medicinal plants, such as Searsia dentata (Prakash and Staden, 2008), Amygdalus 
communis (Namli et al., 2011) and Chlorophytum borivilianum (Ashraf et al., 2014).

It can be concluded that, BA is better than Kin as a cytokinin and 3.0 $\mathrm{mg} \mathrm{L^{-1 }}$ BA was the optimum concentration for shoot multiplication. However, more than this concentration considered a supraoptimum concentration, which led to decreasing in shoot number. These results agree with Hiti-Bandaralage et al. (2017), who reported that cell division is directed by RNA, DNA and protein synthesis, which controlled by optimum concentrations of cytokinins. Suboptimum or supraoptimum concentrations of cytokinins result in adverse effects in shoot regeneration.

\section{Rooting and Acclimatization Stages}

In vitro multiplied shoots (2-4) at least $3 \mathrm{~cm}$ long (clusters) were tested for rooting. Preliminary trials were carried out to stimulate adventitious root formation using different strengths of MS medium and sucrose. Quarter strength MS medium and $30 \mathrm{~g} \mathrm{~L}^{-1}$ sucrose were the best for root induction. Data in table (5) indicate that $1 / 4 \mathrm{MS}$ nutrient medium supplemented with $3 \mathrm{mg} \mathrm{L}^{-1} \mathrm{IBA}$ with $100 \mathrm{mg} \mathrm{L}^{-1} \mathrm{PG}+1 \mathrm{~g} \mathrm{~L}^{-1} \mathrm{AC}$ gave the highest percentage of roots formed per explant $(70 \%)$ (Fig. 1d) with the highest mean number of roots / shoot $(7.5$ roots) and mean length of roots $(7.55 \mathrm{~cm})$. The highest mean length of roots $(8.88 \mathrm{~cm})$ was obtained from medium containing $4 \mathrm{mg} \mathrm{L}^{-1}$ IBA. It is noticed that increasing IBA concentration to $3 \mathrm{mg} \mathrm{L}^{-1}$ resulted in increasing in the percentage of rooting and also increasing in mean number of roots/shoot. However, more than this concentration led to decreasing in both rooting percentage and number of roots/shoot. Sharifian et al. (2009) recorded that phloroglucinol plays an important role in increasing the proportion of shoots that can be rooted. Maximum number of roots were sprouted in woody and medicinal plants in the presence of half strength MS medium, PG and IBA in Diospyros virginiana (Palla and Beasley, 2013) and Tinospora cordifolia (Jani et al., 2015). Also, $100 \%$ in vitro rooting of Prunus empyrean was achieved on half strength MS medium supplemented with $0.5 \mathrm{mg} \mathrm{L}^{-1}$ IBA (Sadeghi et al., 2015). Senarath (2010) found that rooting percentage with full strength MS medium was significantly lower $(20 \%)$ than half strength MS medium $(100 \%)$ in the medicinal plant Coscinium fenestratum. Rooting in Pistacia vera shoots family Anacardiaceae was achieved on $1 / 2$ MS medium supplemented with $2.5 \mathrm{mg} \mathrm{L}^{-1}$ IBA (Benmahioul, 2017).

Also, by studying the effect of different strengths of MS media in rooting of the medicinal plant Typhonium flagelliforme (Rezali et al., 2017). It was found that there was a negative correlation between MS strength and the number of roots. IBA was more effective on root formation in several woody and medicinal plants, Panax ginseng (Kim et al., 2003), Gentiana lutea (Mariya et al., 2011), Plectranthus amboinicus (Rahman et al., 2015) and Bambusa arundinacea (Venkatachalam et al., 2015). 
Table (5). Effect of different concentrations of IBA in $1 / 4$ MS medium supplemented with $100 \mathrm{mg} \mathrm{L}^{-1} \mathrm{PG}+1 \mathrm{~g} \mathrm{~L}^{-1} \mathrm{AC}$ on the in vitro rooting of Searsia tripartita after 8 weeks of culture.

\begin{tabular}{cccc}
\hline $\begin{array}{c}\text { IBA conc. } \\
\left(\mathbf{m g ~ L}^{-1}\right)\end{array}$ & $\begin{array}{c}\text { Rooting } \\
(\mathbf{\%})\end{array}$ & $\begin{array}{c}\text { Mean no. of } \\
\text { roots/cluster }\end{array}$ & $\begin{array}{c}\text { Mean length of } \\
\text { roots }(\mathbf{c m})\end{array}$ \\
\hline $\mathbf{0 . 0}$ & 40 & $1.50^{\mathrm{cd}}$ & $4.20^{\mathrm{cd}}$ \\
$\mathbf{1 . 0}$ & 40 & $3.00^{\mathrm{c}}$ & $4.90^{\mathrm{c}}$ \\
$\mathbf{2 . 0}$ & 50 & $5.25^{\mathrm{b}}$ & $1.45^{\mathrm{e}}$ \\
$\mathbf{3 . 0}$ & 70 & $7.50^{\mathrm{a}}$ & $7.55^{\mathrm{b}}$ \\
$\mathbf{4 . 0}$ & 30 & $1.50^{\mathrm{cd}}$ & $8.88^{\mathrm{a}}$ \\
$\mathbf{5 . 0}$ & 30 & $1.00^{\mathrm{d}}$ & $3.10^{\mathrm{d}}$ \\
\hline
\end{tabular}

In each column, means followed by the same letter are not significantly different ( $p$ $<0.05)$ according to Duncan's multiple range test.

Rooted plantlets of $S$. tripartita were successfully acclimatized in plastic pots in peat moss and soil mixture (1:1). An average of $50-60 \%$ of the in vitro derived transplants was survived and showed normal development as that of the mother plants (Fig. 1e and 1f).
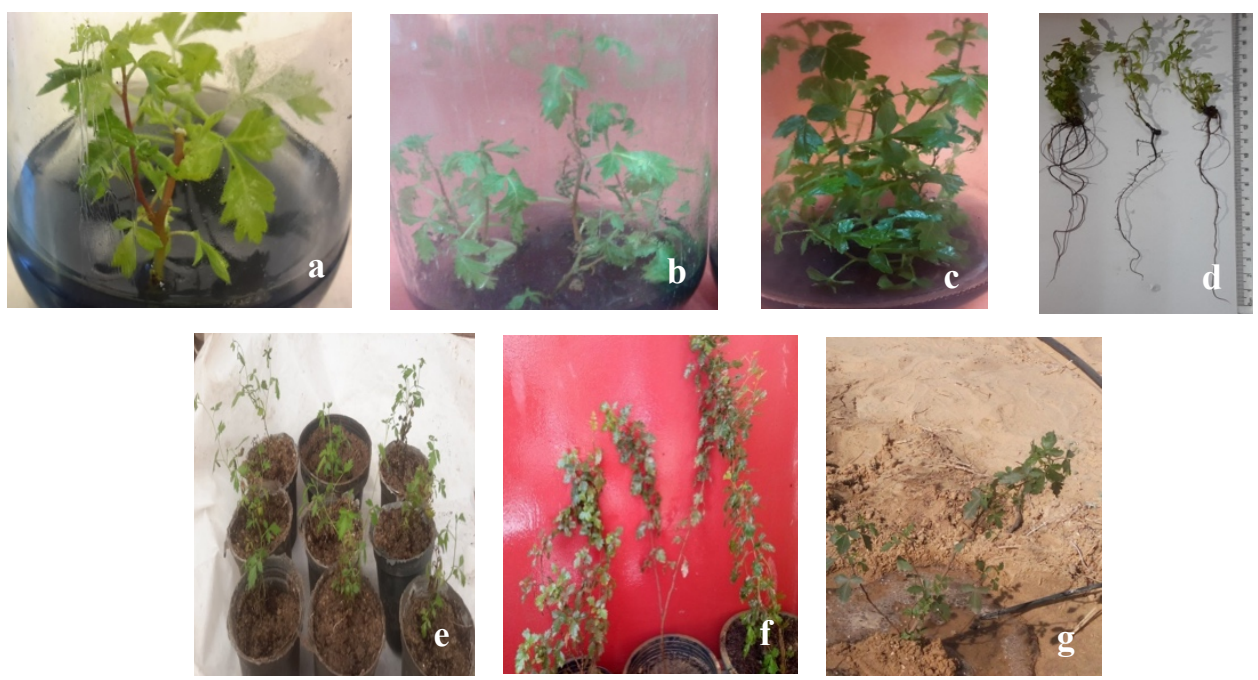

Fig. (1). Micropropagation of Searsia tripartita plant. a. Shoot initiation from stem node sections from mature plants on MS medium containing $0.1 \mathrm{mg} \mathrm{L}^{-1} \mathrm{NAA}$ and $1.0 \mathrm{mg} \mathrm{L}^{-1} \mathrm{BA}$. b. Shoot initiation from juvenile shoot tips on MS medium containing $0.1 \mathrm{mg} \mathrm{L}^{-1}$ NAA and $1.5 \mathrm{mg} \mathrm{L}^{-1}$ BA. c. Shoot multiplication on MS medium containing $3.0 \mathrm{mg} \mathrm{L}^{-1} \mathrm{BA}$. d. Rooting on MS medium containing 3 mg L ${ }^{-1}$ IBA and $100 \mathrm{mg} \mathrm{L}^{-1}$ PG. e. Two months old acclimatized 
plantlets. f. Nine months old acclimatized plantlets. g. Out greenhouse grown plants.

\section{Analysis of Phenolic Content in Searsia tripartita}

In this study, the phenolic content was analyzed and compared between three plant materials; mother plant, in vitro multiplied plant and acclimatized plant. Data in table (6) reveal that, five phenolic compounds were detected. Among them, coumarin amount was the major in all tested tissues followed by ellagic acid. By comparing the amount of the obtained compounds, mother plant showed high amounts of allagic acid, ferulic acid and coumarin than other tissues. These amounts were 5.1, 1.8 and $8.4 \mathrm{mg} \mathrm{g}^{-1}$ dry weight for allagic acid, ferulic acid and coumarin, respectively.

Table (6). A comparison between the concentration of phenolics of the mother plant, in vitro multiplied plants and acclimatized plants of Searsia tripartita.

\begin{tabular}{cccccc}
\hline Sample & \multicolumn{4}{c}{ Concentration of phenolic compounds (mg g $\mathbf{~}^{-1}$ dry weight) } \\
\cline { 2 - 6 } & Ellagic acid & Ferulic acid & Coumarin & Quercetin & Kaempferol \\
\hline $\begin{array}{c}\text { Mother plant } \\
\text { In vitro multiplied }\end{array}$ & 5.1 & 1.8 & 8.4 & 1.2 & 0.4 \\
plants & - & 0.3 & 3.8 & 0.7 & 0.2 \\
Acclimatized plants & 2.0 & 1.2 & 8.2 & 1.5 & 0.5 \\
\hline
\end{tabular}

Whereas in the acclimatized plants, they were present at 2.0,1.2 and $8.2 \mathrm{mg} \mathrm{g}^{-1}$ for the allagic acid, ferulic acid and coumarin, respectively. This can be explained by the biotic or abiotic stresses, which face plants grown under environmental conditions (Mallick et al., 2016). These difficult conditions trigger plants to produce large amounts of some secondary metabolites. On the contrast, the amount of quercetin and kaempferol were high in the acclimatized plants than in the mother plant that were 1.5 and 0.5 $\mathrm{mg} / \mathrm{g}$, respectively in the acclimatized plants; although they were 1.2 and 0.4 $\mathrm{mg} \mathrm{g}^{-1}$, respectively in the mother plant. Production of high amount of some phenolic compounds in the acclimatized plants may be a kind of adaptation due to the sensitivity of the plant to the new environment until it becomes resistant (Jeeshna and Paulsamy, 2011).

In the in vitro multiplied plants, only four phenolics were detected in small amounts than both of the mother and the acclimatized plants (Table 6). This can be explained by another kind of stress faces the plantlets grown under controlled conditions. Since the production of some secondary metabolites are temperature dependent enzymes. Therefore, the production of some biochemical substances in the same plant may not be similar under different conditions (Jeeshna and Paulsamy, 2011).

It can be concluded that, it is important to apply the in vitro propagation protocol for the production of $S$. tripartita through shoot tips 
and stem node section explants and conserve this endangered plant, which contains phenolic compounds with several health benefits. Further studies using different elicitors should be conducted to produce these phenolics in a large scale in the in vitro multiplied plants.

\section{REFERENCES}

Al-Kurdi, R., H. Khalaif and D. Al-Eissawi (2000). Effectiveness of selected plant extracts in inhibiting Agrobacterium tumefaciens in vitro and in suppressing tumor formation on tomato roots in greenhouse. Dirasat Agricultural Science, 27 (1): 10-19.

Ashraf, M.F., M. Abd Aziz, N. Kemat and I. Ismail (2014). Effect of cytokinin types, concentrations and their interactions on in vitro shoot regeneration of Chlorophytum borivilianum Sant. \& Fernandez. Electronic Journal of Biotechnology, 17: 275-279.

Benmahioul, B. (2017). Factors affecting in vitro micropropagation of Pistachio (Pistacia vera) L. Agriculture and Forestry Journal, 1 (1): 56-61.

Cheruvathur, M.K., J. Abraham and T.D. Thomas (2015). In vitro micropropagation and flowering in Ipomoea sepiaria Roxb. An important ethanomedicinal plant. Asian Pacific Journal of Reproduction, 4 (1): 49-53.

Chintalwar, G.J., S. Gupta, G. Roja and V.A. Bapat (2003). Protoberberine alkaloids from callus and cell suspension cultures of Tinospora cordifolia. Pharmaceutical Biol., 41 (2): 81-87.

Dan, Y. and N.A. Reichert (2001). Cytokinin metabloism and action. Annual Review of Plant Physiology and Plant Molecular Biology, 52: 89118.

Das, P. and A.K. Srivastav (2015). To study the effect of activated charcoal, ascorbic acid and light duration on in vitro micropropagation of Aloe vera L. International Journal of Innovative Research in Science, Engineering and Technology, 4 (5): 3131- 3138.

Duncan, B.D. (1955). Multiple range and multiple F tests. Biometrics, 11: 142.

El-hadidi, M.N., K.H. Batanouny and A.G. Fahmy (1991). In: "The Egyptian Plant Red Data Book". Vol. 1: Trees and Shrubs. Cairo, UNEP, $226 \mathrm{pp}$.

Fracaro, F. and S. Echeverrigaray (2001). Micropropagation of Cunila galioides, a popular medicinal plant of south Brazil. Plant Cell, Tissue and Organ Culture, 64: 1-4.

Furth, D.G. and D.A. Young (1988). Relationships of herbivore feeding and plant flavonoids (coleopteran: chrysomelidae and anacardiacea: Rhus). Oecologia, 74 (4): 496-500. 
Gargoubi, S., N. Ladhari, C. Boudoukhane, B. Mechri, M. Hammami and F. Sakli (2015). 26 Tunisian Populations of Rhus tripartita (Ucria): A promising source of natural dyes for textile application. International Journal of Applied Research, 3 (2): 26-34.

George, E.F., M.A. Hall and G.J.D. Klerk (2008). In: "Plant Propagation by Tissue Culture". $3^{\text {rd }}$ Ed. Chapter 5: Plant Growth Regulators I: Introduction; Auxins, their Analogues and Inhibitors. Springer, p. 175-204.

Hartmann, H.T. and D.F. Kester, (1983). In: "Plant Propagation, Principles and Practices". $4^{\text {th }}$ Ed. Prentice Hall, IWC. England, New Jersey.

Hiti-Bandaralage, J.C.A., A. Hayward and N. Mitter (2017). Micropropagation of Avocado (Perseaamericana Mill.). American Journal of Plant Sciences, 8: 2898-2921.

Hu, C.Y. and P.J. Wang (1983). In: "Meristem, Shoot Tip and Bud Culture". Evans, D.A., W.P. Sharp, P.V. Ammirato and Y. Yamada (Eds.). Handbook of Plant Cell Culture, Vol. I, Macmillan Publ. Co., New York, p.177-227.

Itidel, C., M. Chokri, B. Mohamed and Z. Yosr (2013). Antioxidant activity, total phenolic and flavonoid content variation among Tunisian natural populations of Rhus tripartita (Ucria) Grande and Rhus pentaphylla Desf. Industrial Crops and Products, 51: 171-177.

Jamal, M.A.H.M., R.B. Rahman, D. Kumar and R. Islam (2011). In vitro regeneration for mass propagation in commercial scale of medicinal plant Vitex nigundo L. Journal of Bio-Science, 18: 140- 145.

Jani, J.N., S.K. Jha, D.S. Nagar, R.S. Chauhan and H. Hegde (2015). Phloroglucinol plays role in shoot bud induction and in vitro tuberization in Tinospora cordifolia- a medicinal plant with multitherapeutic application. Advanced Techniques in Biology and Medicine, 3: 2.

Jeeshna, M.V. and S. Paulsamy (2011). Evaluation of certain flavonoids of medicinal importance in the wild and micropropagated plants of the endangered medicinal species, Exacum bicolor Roxb. Journal of Applied Pharmaceutical Science, 1 (5): 99-102.

Keng, C.L., L.S. Yee and P.L. Pin (2009). Micropropagation of Gynura procumbens (Lour.) Merr. an important medicinal plant. Journal of Medicinal Plants Research, 3 (3): 105-111.

Kim, Y.S., E.J. Hahn, E.C. Yeung and K.Y. Paek (2003). Lateral root development and saponin accumulation as affected by IBA or NAA in adventitious root cultures of Panax ginseng CA Meyer. In vitro Cell. Develop. Biol., 39: 245-249.

Kumar, N. and V. Pruthi (2014). Potential applications of ferulic acid from natural sources. Biotechnology Reports, 4: 86-93.

Kumar, R., S. Vijayalakshmi and S. Nadanasabapathi (2017). Health benefits of quercetin. Defence Life Science Journal, 2 (2): 142-151.

Egyptian J. Desert Res., 67, No. 2, 359-377 (2017) 
Mahjoub, M.A., S. Ammar, H. Edziri, N. Mighri, A. Bouraoui and Z. Mighri. (2010). Anti-inflammatory and antioxidant activities of some extracts and pure natural products isolated from Rhus tripartitum (Ucria). Med Chem. Res., 19: 271-282.

Mallick, B., S. Sinha and D. Roy (2016). Evaluation of antioxidative potential of field grown and tissue culture derived Mentha piperita L. Plants. Int. J. Curr. Microbiol. App. Sci., 5 (3): 382-391.

Mariya, P., Z. Ely and V. Antonina (2011). Effect of silver nitrate on in vitro root formation of Gentiana lutea. Romanian Biotechnological Letters, 16: 53-58.

Mohammed, A.I. (2015). Phytoconstituents and the study of antioxidant, antimalarial and antimicrobial activities of Rhus tripartita growing in Egypt. Journal of Pharmacognosy and Phytochemistry, 4 (2): 276281.

Montano, J.M.C., E.B. Moron, C.P. Guerrero and M.L. Lazaro (2011). A review on the dietary flavonoid kaempferol. Mini-Reviews in Medicinal Chemistry, 11: 298-344.

Murashige, T. (1974). Plant propagation through tissue cultures. Ann. Rev. Plant Physiol., 25: 135-166.

Murashige, T. and F. Skoog (1962). A revised medium for rapid growth and bioassays with tobacco tissue culture. Physiologia Plantarum, 15: 473-479.

Namli, S., C. Isikalan, F. Akbas and D. Basaran (2011). Improved in vitro rooting of almond (Amygdalus communis) cultivar. Plant Omics Journal, 4 (1): 14-18.

Oliveira, L.S.D., G.E. Brondani, K.D.B. Piotto, R. Calsavara, A.N. Gonçalves and M.D. Almeida (2015). Micropropagation of Eucalyptus cloeziana mature trees. Australian Forestry, 78 (4): 219-231.

Padte, T., S. Pednekar and P. Shejwalkar (2017). Applications of coumarins as cardiovascular and anti-cancer agents: a short review. Journal of Cardiology and Cardiovascular Therapy, 8 (5).

Palla, K.J. and R.R. Beasley (2013). In vitro culture and rooting of Diospyros virginiana L. Hortscience, 48 (6): 747-749.

Prakash, S. and J.V. Staden (2008). Micropropagation of Searsia dentate. In vitro Cellular and Developmental Biology Plant, 44 (4): 338- 341.

Rahman, Z.A., E.S.M. Noor, M.S.M. Ali, R. Mirad and A.N. Othman (2015). In vitro micropropagation of a valuable medicinal plant, Plectranthus amboinicus. American Journal of Plant Sciences, 6: 1091-1097.

Ranjitha Kumari, B.D., P. Velayutham and S.A. Anitha (2007). Comparative study on inulin and esculin content of in vitro and in vivo plants of Chicory (Cichorium intybus L. cv. Lucknow Local). Advances in Biological Research, 1 (1-2): 22-25. 
Rezali, N.I., N.J. Sidik, A. Saleh, N.I. Osman and N.A.M. Adam (2017). The effects of different strength of MS media in solid and liquid media on in vitro growth of Typhonium flagelliforme. Asian Pacific Journal of Tropical Biomedicine, 7 (2): 151-156.

Rispail, N., P. Morrand and K.J. Webb (2005). In: "Phenolic Compounds: Extraction and Analysis. Lotus Japonicas Handbook (Márquez, A.J. Ed.), p. 349-355.

Sadeghi, F., A. Yadollahi, M. Jafarkhani Kermani and M. Eftekhari (2015). Optimizing culture media for in vitro proliferation and rooting of Tetra (Prunus empyrean) rootstock. Journal of Genetic Engineering and Biotechnology, 13: 19-23.

Shahat, A.A., M.S. Alsaid, S. Rafatullah, M.O. Al-Sohaibani, M.K. Parvez, M.S. Al-Dosari, V. Exarchou and L. Pieters (2016). Treatment with Rhus tripartita extract curtails isoproterenol-elicited cardiotoxicity and oxidative stress in rats. Complementary and Alternative Medicine, 16: 351.

Senarath, W.T.P.S.K. (2010). In vitro propagation of Coscinium fenestratum (Gaertn.) Colebr. (Menispermaceae) an endangered medicinal plant. J. Nat. Sci. Foundation Sri. Lanka, 38 (4): 219-223.

Sharifian, S., K. Vahdati, M. Mirmasoumi and S.A.G. Maghami (2009). Assessment of phloroglucinol effect on rooting of tissue cultured Persian walnut. Acta Horticulturae, 812: 189-196.

Singh, P. and R.M. Patel (2016). Factors affecting in vitro degree of browning and culture establishment of pomegranate. African Journal of Plant Science, 10 (2): 43-49.

Täckholm, V. (1974). In "Student Flora of Egypt”. Cairo University Press, Egypt.

Venkatachalam, P., K. Kalaiarasi and S. Sreeramanan (2015). Influence of plant growth regulators (PGRs) and various additives on in vitro plant propagation of Bambusa arundinacea (Retz.) Wild: A recalcitrant bamboo species. Journal of Genetic Engineering and Biotechnology, 13: 193-200.

Ye, Q., E. Bunn and K.W. Dixon (2011). Failure of sexual reproduction found in micropropagated critically endangered plants prior to reintroduction: a cautionary tale. Botanical Journal of the Linnean Society, 165 (3): 278-284.

Yildiz, M., S. Ozcan, and C. Er (2002). The effect of different explant sources on adventitious shoot regeneration in flax (Linum usitatissimum L.). Turkish Journal of Biology, 26: 37-40.

Zhang, H.M., L. Zhao, H. Li, H. Xu, W.W. Chen and L. Tao (2014). Research progress on the anticarcinogenic actions and mechanisms of ellagic acid. Cancer Biol. Med., 11: 92-100.

Egyptian J. Desert Res., 67, No. 2, 359-377 (2017) 


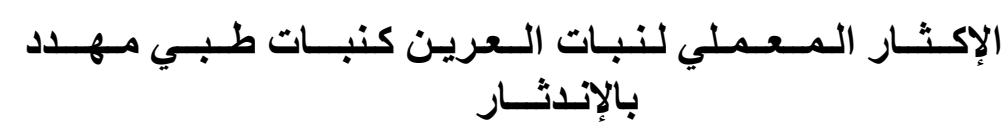

هبة السيد غريب* ومهرية فريد جبر

قسم الأصول الور اثثية، مركز بحوثةث الصحر اءو، المطرية، القاهرة، مصر

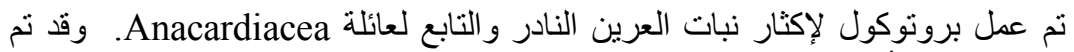

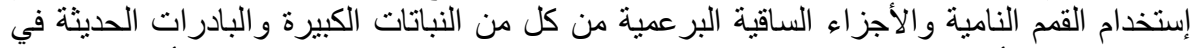

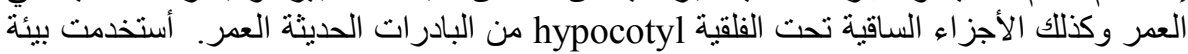

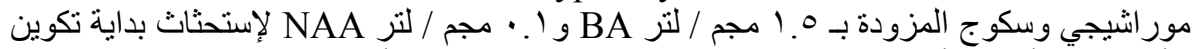

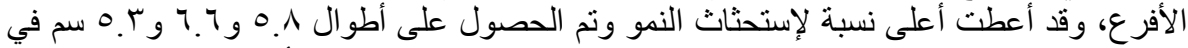

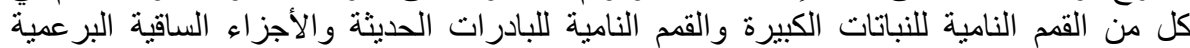

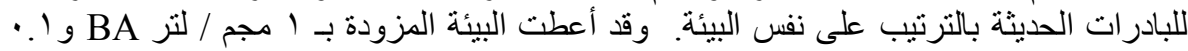

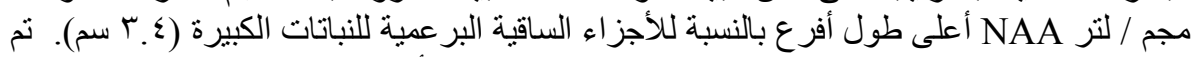

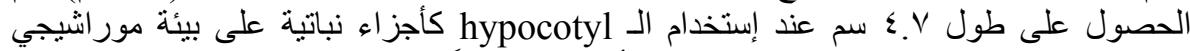

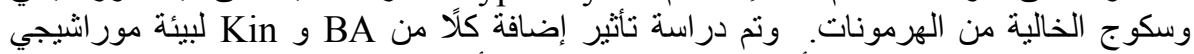

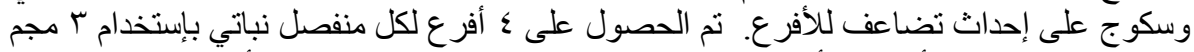

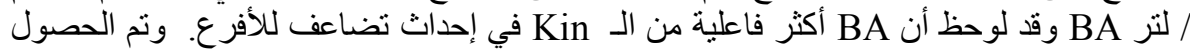

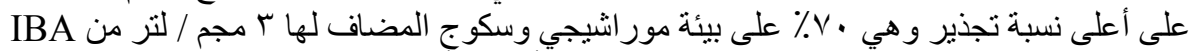

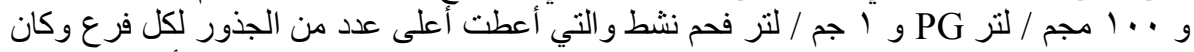

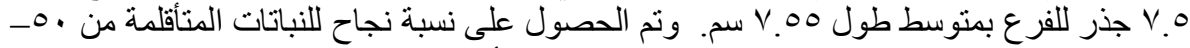

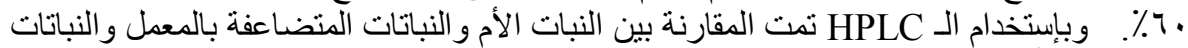

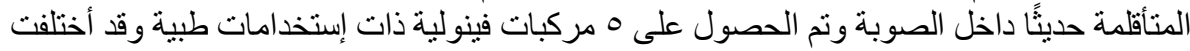

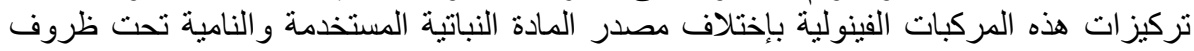

